\title{
Preliminary Characterization of Cell-free K99 Antigen Isolated from Escherichia coli B41
}

\author{
By J. A. MORRIS, A. E. STEVENS AND W. J. SOJKA \\ Central Veterinary Laboratory, Weybridge, Surrey
}

(Received I I October 1976)

\begin{abstract}
SUMMARY
The $\mathrm{K} 99$ antigen of Escherichia coli $\mathrm{B} 4 \mathrm{I}$ was isolated by isoelectric precipitation from heated bacterial suspensions. Chromatography and immunoabsorption experiments suggested that the mannose-resistant haemagglutinating activity of partially purified preparations of antigen was K99. The antigen was partially susceptible to bacterial proteases and was inactivated by periodate oxidation. Haemagglutination inhibition experiments with sugars and absorption of K99 with antisera to human blood groups A and B substances suggested that K99 contains a terminal $\alpha$-linked $N$-acetylgalactosamine moiety, which is involved in the haemagglutination reaction, and an adjacent terminal $\alpha$-linked galactose moiety, which plays no part in the reaction.
\end{abstract}

\section{INTRODUCTION}

Most Escherichia coli strains enteropathogenic for calves and lambs contain a common surface antigen which was originally referred to as Kco (Sojka, unpublished; Smith \& Linggood, I972) but has now been established as the $E$. coli K99 antigen (Ørskov et al., 1975). Smith \& Linggood (1972) demonstrated that the production of K99 was controlled by a transmissible plasmid and that strains which possessed the K99 plasmid proliferated in the anterior small intestine of calves and lambs while those pretreated with acridine orange did not. They therefore suggested that the K99 antigen may facilitate adhesion to the intestinal epithelium of lambs and calves in a similar manner to the K88 antigen found in some of the pig enteropathogenic strains (Smith \& Linggood, 1971; Jones \& Rutter, 1972).

To study the pathogenesis of enteric colibacillosis in calves and lambs and hence develop an effective vaccine, cell-free preparations of the $\mathrm{K}_{99}$ antigen are needed. This paper reports the isolation and chemical properties of partially purified K99 from $E$. coli B4I, the recommended reference strain (Ørskov et al., 1975).

\section{METHODS}

Preparation of $\mathrm{K} 99$ antigen. The $\mathrm{K} 99$ antigen was isolated by a method similar to that used to isolate the K88 antigen (Stirm et al., 1967). Escherichia coli B4I (O101 : K99: H-) was grown on fresh blood agar in Roux flasks for $18 \mathrm{~h}$ at $37^{\circ} \mathrm{C}$ and harvested in saline. The $\mathrm{K} 99$ antigen was extracted by gently shaking the bacterial suspension at $60^{\circ} \mathrm{C}$ for $30 \mathrm{~min}$, removing the bacteria by centrifuging and adjusting the $\mathrm{pH}$ of the supernatant fluid to $4^{\circ} \mathrm{O}$ with dilute acetic acid. Crude antigen precipitated overnight at $4{ }^{\circ} \mathrm{C}$; it was washed in

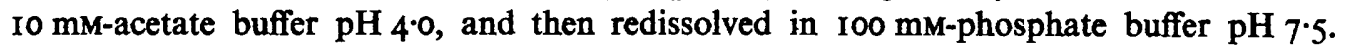
The $\mathrm{K}_{99}$ was partially purified by five cycles of precipitation and redissolved to give a protein concentration of $8 \mathrm{mg} \mathrm{ml}^{-1}$. 
Antisera. Antiserum to K99 was prepared in rabbits using E. coli strain 'BII7' (O8:K85ab,K99-:H-). It was rendered monospecific by absorption with $E$. coli strains $\mathrm{G} 7(\mathrm{O} 8: \mathrm{K} 87, \mathrm{~K} 88 \mathrm{ab})$ and $\mathrm{E68I}$ I (O14I:K85ab) to remove agglutinins to $\mathrm{O} 8$ and $\mathrm{K} 85 \mathrm{ab}$ antigens using the techniques described by Sojka (1965).

Antisera to human blood groups A and B substances were a gift from the South London Regional Blood Transfusion Centre.

Serological techniques. Ouchterlony double diffusion tests were performed in agar gels (Stirm et al., 1967) using $20 \mu \mathrm{l}$ samples. Plates were incubated in a humidity cabinet at $37^{\circ} \mathrm{C}$ for 3 days. Specific precipitin tests were used to identify K99 during the isolation and purification processes but these were unnecessary once it was established that the antigen could be assayed by haemagglutination.

Haemagglutination tests. Direct haemagglutination tests were performed in microtitre trays using $50 \mu \mathrm{l}$ portions of $3 \%$ red blood cells and K99 preparations. Trays were incubated at $4{ }^{\circ} \mathrm{C}$ and examined after $2 \mathrm{~h}$. Sheep red blood cells were used in all of the studies and human blood group $\mathrm{O}$ red cells were used as indicated. The highest dilution of antigen which gave complete agglutination was defined as one haemagglutinating unit (h.u.). Standard preparations of K99 usually contained 128 h.u.

Column chromatography. Gel filtration was done in columns $(26 \times 700 \mathrm{~mm})$ of Sepharose 4B (Pharmacia) using $100 \mathrm{~mm}-\mathrm{Tris} / \mathrm{HCl}$ buffer, $\mathrm{pH} 8 \cdot 0$. Fractions $(2.0 \mathrm{ml})$ were eluted by upward development of eluant at a flow rate of $20 \mathrm{ml} \mathrm{h}^{-1}$ at room temp. Ion exchange chromatography was done on columns $(9 \times 300 \mathrm{~mm})$ of QAE Sephadex A50 (Pharmacia) equilibrated with $100 \mathrm{~mm}$-phosphate buffer $\mathrm{pH} 7^{\circ} 0$. Antigen from the void volume of the Sepharose $4 \mathrm{~B}$ column was dialysed against starting buffer and a sample ( $2 \mathrm{mg}$ protein) was applied to the Sephadex column which was developed using an increasing stepwise $\mathrm{NaCl}$ gradient in $10 \mathrm{mM}$-phosphate buffer $\mathrm{pH} 7 \cdot 0$ at room temp.

Chemical analysis. The protein content of K99 preparations was determined by the method of Lowry et al. (195I) using Wellcomtrol sera as standard (Wellcome Reagents). Carbohydrate was estimated by the method of Dubois et al. (1956) using D-glucose as standard, and lipid was determined using a commercially available test kit for total lipid (Boehringer).

Degradation studies. The susceptibility of $\mathrm{K}_{99}$ to the following enzymes was examined: trypsin, carboxypeptidase and leucine aminopeptidase (each at $\mathrm{I} \mathrm{mg} \mathrm{ml}^{-1}$ ), chymotrypsin (1.5 $\left.\mathrm{mg} \mathrm{m}^{-1}\right)$, papain $\left(2.5 \mathrm{mg} \mathrm{m}^{-1}\right)$, bromelain, Bacillus subtilis protease, Streptomyces griseus pronase, $\alpha$-amylase, $\beta$-amylase, $\alpha$-glucosidase, $\beta$-galactosidase, muramidase and neuraminidase (each at $5 \mathrm{mg} \mathrm{ml}^{-1}$ ), DNAase and lipase (each at $\mathrm{I} \mathrm{mg} \mathrm{m}^{-1}$ ). Enzymes were obtained from Sigma, except neuraminidase which was from Boehringer. All enzymes, except $\beta$-galactosidase, were incubated with $\mathrm{K} 99$ in $100 \mathrm{mM}$-phosphate buffer $\mathrm{pH} 7.5$ for $18 \mathrm{~h}$ at $37^{\circ} \mathrm{C}$. The action of $\beta$-galactosidase was tested in $10 \mathrm{~mm}$-acetate buffer $\mathrm{pH} 5.0$; after incubation, the reaction mixture was adjusted to $\mathrm{pH} 7.5$ by adding $100 \mathrm{mM}-\mathrm{Na}_{2} \mathrm{HPO}_{4}$. Controls without any enzyme were treated similarly. At first, the low molecular weight enzymes were rcmoved by selective dialysis through Minicon S-I 25 concentrators (Amicon, High Wycombe, Buckinghamshire) before testing for K99 activity. It was subsequently found that at $4{ }^{\circ} \mathrm{C}$ the enzymes did not affect the haemagglutination tests, and in later experiments these were done directly on the reaction mixtures.

Susceptibility to periodate was determined by incubation at $4{ }^{\circ} \mathrm{C}$ for $30 \mathrm{~min}$, and to dithiothreitol and formaldehyde by incubation at room temp. for $2 \mathrm{~h}$ and $30 \mathrm{~min}$ respectively. Each agent was the removed from the reaction mixture using Minicon S-I25 concentrators. 
Table I. Chemical analysis of a standard preparation of K99 antigen

$\begin{array}{lcc} & \text { Concn }\left(\mathrm{mg} \mathrm{ml}^{-1}\right) \text { in antigen: } \\ \begin{array}{c}\text { After Ist } \\ \text { precipitation }\end{array} & \begin{array}{c}\text { After } 5 \text { th } \\ \text { precipitation }\end{array} \\ \text { Protein } & 13.90 & 8.20 \\ \text { Carbohydrate } & 0.96 & 0.55 \\ \text { Lipid } & <0.1 & <0.1 \\ \text { Protein:carbohydrate } & \text { I4.5:I } & 14.9: 1\end{array}$

Sugar blocking studies. Competitive inhibition of K99 haemagglutination was studied by titrating the antigen in the presence of an equal volume of $2 \%(w / v)$ sugar solution. Sheep and human blood group $\mathrm{O}$ red cells were examined. Galactose, glucose and mannose, together with their amino and acylamino derivatives, $N$-acetylneuraminic acid, fucose, rhamnose and muramic acid were examined. Galactose, galactosamine, $N$-acetylgalactosamine, glucose, glucosamine and fucose were also examined at concentrations up to $15 \%(\mathrm{w} / \mathrm{v})$.

In some experiments sheep or human blood group $\mathrm{O}$ red cells were incubated with an equal volume of $\mathrm{N}$-acetylgalactosamine for $3 \mathrm{~h}$ at $4^{\circ} \mathrm{C}$ or at $37^{\circ} \mathrm{C}$, and then centrifuged and resuspended in buffer for use in the haemagglutination test with untreated K99. Preparations of $\mathrm{K} 99$ were treated similarly and the sugar was removed by selective dialysis in Minicon S-I25 concentrators. The treated antigen was then titrated using untreated sheep red cells.

Immunoabsorption studies. Monospecific antiserum to K99 or human blood groups A or B substances was used to absorb preparations of K99. Equal volumes of antiserum and antigen were incubated at $37^{\circ} \mathrm{C}$ for $18 \mathrm{~h}$ and any sediment was removed by centrifuging.

Suspensions of $3 \%$ sheep red cells and human blood group $\mathrm{O}$ red cells were absorbed in a similar manner with antisera to human blood groups A or B substances, washed once in buffer and resuspended to their original concentration.

\section{RESULTS}

Column chromatography. Haemagglutinating activity and gel precipitin activity were detected in the material eluting in the void volume of Sepharose $4 \mathrm{~B}$ columns. The precipitin and haemagglutinin eluted together as a single peak on QAE Sephadex A50 columns with $300 \mathrm{~mm}-\mathrm{NaCl}$. No other peaks were observed.

Chemical analysis. Only protein and carbohydrate were detected on analysis, and the ratio of one to the other did not alter significantly on repeated precipitation (Table I).

Degradation studies. Bacillus subtilis protease and Streptomyces griseus pronase both reduced the activity of K 99 preparations by $4 \mathrm{~h}$.u. None of the other enzymes examined affected the activity of the antigen. Sodium periodate oxidation reduced the antigen activity by $32 \mathrm{~h} . \mathrm{u}$. whilst formaldehyde caused a reduction of $128 \mathrm{~h}$.u.

Sugar blocking studies. Of the sugars examined, only $\mathrm{N}$-acetylgalactosamine inhibited haemagglutination of sheep red cells by K99: activity decreased by 32 h.u. with a $2 \%$ solution but by only 2 h.u. with a $1 \%$ solution. When either K99 or sheep red cells were pre-treated with $N$-acetylgalactosamine, activity was unaffected.

Human blood group $\mathrm{O}$ red cells agglutinated when treated with $2 \% \mathrm{~N}$-acetylgalactosamine. Again none of the other sugars examined affected the haemagglutination of these human red cells by $\mathrm{K} 99$. 
Immunoabsorption. Absorption of K99 with antisera to K99 reduced the activty of the antigen by only 32 h.u. while antisera to human blood groups A or B substances each reduced the $\mathrm{K} 99$ activity by $\mathrm{I} 28$ h.u. These results showed no dependence on the species of red cell used to assay the absorbed antigen.

Sheep red cells absorbed with antisera to either human blood groups A or B substances gave the same haemagglutination titre with $\mathrm{K}_{99}$ as untreated red cells although some haemolysis occurred during absorption. There was no haemolysis when human blood group $O$ red cells were absorbed and the haemagglutination titre using these cells was similarly unaffected.

\section{DISCUSSION}

The technique of extracting $E$. coli $\mathrm{K} 99$ antigen by isoelectric precipitation from heated bacterial suspensions differs from that described for the isolation of the K88 antigen only in the $\mathrm{pH}$ required (Stirm et al., 1967). Throughout the chromatographic studies the gel precipitin activity of a K99 preparation could not be dissociated from the eluting mannoseresistant haemagglutinating activity. Similarly, absorption of antigen with monospecific antiserum to $\mathrm{K} 99$ abolished haemagglutination suggesting that the eluting mannose-resistant haemagglutinin in the extracts was probably K99. Chemical analysis showed that the major component of $\mathrm{K} 99$ was polypeptide, although traces of carbohydrate were also detected. The K88 antigen is also an eluting mannose-resistant haemagglutinin (Jones \& Rutter, 1974) and is thought to be a pure protein usually contaminated with carbohydrate (Stirm et al., I967). Enzyme studies confirmed, in part, the chemical nature of K99, although the polypeptide was only susceptible to bacterial proteases. The resistance of K99 to mammalian proteases was not unexpected (see also Stirm, Ørskov \& Ørskov, I966). Trypsin and chymotrypsin are pancreatic endopeptidases active in the anterior small intestine. Carboxypeptidase is also a pancreatic enzyme while leucine aminopeptidase is in the intestinal mucosa (Mahler \& Cordes, 197I).

The results of the periodate oxidation and chemical analysis are consistent with K99 being a glycoprotein, although the action of glycoside hydrolases could not confirm this. When a glycoprotein has an affinity for a cell membrane, the carbohydrate moiety is often responsible for its binding to a receptor on that membrane. Therefore treatment of K99 to remove or destroy carbohydrate might reduce the haemagglutination activity and, indeed, periodate oxidation did destroy the activity, although this could have resulted from the oxidation of any hydroxyamino acids which might be present in K99. Competitive inhibition of K99 haemagglutination by the sugars commonly associated with glycoproteins was only shown by $\mathrm{N}$-acetylgalactosamine which suggested that the antigen contains a terminal $\mathrm{N}$-acetylgalactosamine residue or that this sugar acts as the $\mathrm{K} 99$ receptor on the red cell membrane. This could not be resolved by haemagglutination experiments using K99 or red cells absorbed with $N$-acetylgalactosamine.

$N$-Acetylgalactosamine and galactose are the immunodominant sugars in human blood groups A and B substances respectively (Watkins, 1972). Consequently antisera used in the typing of human blood groups are monospecific for the relevant $\alpha$-linked sugar. The decrease in haemagglutinating activity when $\mathrm{K} 99$ was absorbed with antiserum to human blood group A substance, and the unaffected activity of untreated antigen titrated with absorbed red cells, indicated that terminal $N$-acetylgalactosamine is part of the K99 antigen. Absorption experiments using antiserum to human blood group B substance implied that K99 also contains terminal $\alpha$-linked galactose. However, as free galactose did not prevent haemagglutination the terminal galactose must be sufficiently close to terminal $N$-acetyl- 
galactosamine for human blood group B antiserum to interfere with the binding of the latter to the red cell. Thus, the $\mathrm{K} 99$ antigen of $E$. coli $\mathrm{B41}$ appears to be a glycoprotein containing a terminal $\alpha$-linked $N$-acetylgalactosamine moiety, which is involved in the haemagglutination reaction with sheep and human blood group $O$ red cells, and an adjacent terminal $\alpha$-linked galactose moiety, which plays no part in the haemagglutination reaction.

Further studies on the adhesion of enteropathogenic $E$. coli should lead to a better understanding of the interactions between the pathogen and the host cell surface. This would be of value in controlling colibacillosis in farm animals either by using relevant vaccines or by seeking breeding stock which lack the K99 receptors on their intestinal mucosa.

We express our gratitude to Mrs M. Leak of the South London Regional Blood Transfusion Centre for gifts of antisera to human blood groups A and B substances. We also thank Miss P. Wiles for her excellent technical assistance.

\section{REFERENCES}

Dubois, M., Gilles, K. A., Hamilton, J. K., Rebers, P. A. \& Smith, F. (1956). Colorimetric method for the determination of sugars and related substances. Analytical Chemistry 28, 350-356.

Jones, G. W. \& RutTer, J. M. (1972). Role of the K99 antigen in the pathogenesis of neonatal diarrhoea caused by Escherichia coli in piglets. Infection and Immunity 6, 918-927.

JONES, G. W. \& RUTTER, J. M. (1974). The association of K88 antigen with haemagglutinating activity of porcine strains of Escherichia coli. Journal of General Microbiology 84, 135-144.

Lowry, O. H., Rosebrough, N. J., FARR, A. L. \& RANDALI, R. J. (I95I). Protein measurement with the Folin phenol reagent. Journal of Biological Chemistry x93, 265-275.

Mahler, H. R. \& Cordes, E. H. (1971). Biological Chemistry, 2nd edn. London: Harper \& Row.

Ørskov, I., Ørskov, F., SMrTh, H. W. \& SoJKA, W. J. (1975). The establishment of K99, a thermolabile, transmissible Escherichia coli antigen, previously called 'Kco', possessed by calf and lamb enteropathogenic strains. Acta pathologica et microbiologica scandinavica B83, 3 I-36.

SmITH, H. W. \& LINGGOOD, M. A. (197I). Observations on the pathogenic properties of K88, Hly and Ent plasmids of Escherichia coli with particular reference to porcine diarrhoea. Journal of Medical Microbiology 4, 467-486.

SmIth, H. W. \& LINGGOOD, M. A. (1972). Further observations on Escherichia coli enterotoxins with particular regard to those produced by atypical piglet strains and by calf and lamb strains: the transmissible nature of these enterotoxins and of a $\mathbf{K}$ antigen possessed by calf and lamb strains. Journal of Medical Microbiology 5, 243-250.

SoJKA, W. J. (1965). Escherichia coli in Domestic Animals and Poultry. Farnham Royal: Commonwealth Agricultural Bureaux.

STIRM, S., ØRSKOV, I. \& ØRSKOV, F. (1966). K88, an episome-determined protein antigen of Escherichia coli. Nature, London 209, 507-508.

StTRM, S., ØRSKov, F., ØrSKov, I. \& MANSA, B. (1967). Episome-carried surface antigen K88 of Escherichia coli. II. Isolation and chemical analysis. Journal of Bacteriology 93, 73I-739.

WATKINS, W. M. (I972). Blood group substances. In Glycoproteins, vol. B, 2nd edn. Edited by A. Gottschalk. Amsterdam: Elsevier. 